BJHS: Themes 4: 29-53, 2019. C British Society for the History of Science 2019. This is an Open Access article, distributed under the terms of the Creative Commons Attribution-NonCommercialNoDerivatives licence (http://creativecommons.org/licenses/by-nc-nd/4.0/), which permits noncommercial re-use, distribution, and reproduction in any medium, provided the original work is unaltered and is properly cited. The written permission of Cambridge University Press must be obtained for commercial re-use or in order to create a derivative work.

doi:10.1017/bjt.2019.1 First published online 25 July 2019

\title{
The blood that remains: card collections from the colonial anthropological missions
}

\author{
RICARDO ROQUE*
}

\begin{abstract}
In this paper I discuss the history of colonial collections through a focus on the social life of a set of blood group cards held by Portuguese institutions since the 1950s. Between the 1940s and 1960s, a series of anthropological field expeditions were organized by the Portuguese Overseas Science Research Board to the then Portuguese colonies in Africa and Asia. A large number of samples of indigenous blood were collected on blood group paper cards in the course of these campaigns. The cards were then stored in Portugal and used for racial serological studies until the 1980s. Thereafter, the collection survived various institutional deaths. Throughout its post-colonial existence in Portuguese institutions, the cards seem to have moved ambivalently between a condition of valued asset and one of obsolete material. And yet they revealed a resilient capacity to mediate conceptions of historical time. Thus the essay asks what it might mean to approach these collections as colonial 'chronotope' - devices for connecting space and time - and how and why they endured through various ends, culminating as a genetically contaminated museum object.
\end{abstract}

This essay explores the historicity of colonial collections by tracing the social life of a set of blood group cards currently held in a Portuguese museum institution. I draw on archival records, ethnographic encounters and interviews to analyse how these collections mediate relationships between the past, present and future of colonial empire,

* Instituto de Ciências Sociais, Universidade de Lisboa, Portugal. Email: Ricardo.roque@ics.ulisboa.pt.

An earlier version of this paper was presented at the How Collections End workshop in Cambridge in 2017 and at the FOLK conference in Oslo in 2018. I thank the organizers and the participants for comments and remarks on the earlier version. Research for this essay was funded by FCT, Fundação para a Ciência e Tecnologia, Portugal (grant reference PTDC/HAR-HIS/28577/2017). I am grateful to Luís Souto de Miranda, Helena Moreira, Vítor Rosado Marques and Maria Cristina Neto for generously sharing their knowledge, memories and experiences; to Rita Poloni and Cláudia Castelo for sharing research materials; to Ana Canas, director of the Arquivo Histórico Ultramarino, and staff archivists, especially João Santos and Catarina Mateus, for support in accessing the documents of the anthropological missions; and to Susana Garcia, Marta Lourenço and Catarina Teixeira for research access to the collections of the National Museum of Natural History and Science. Ana Rita Amaral, Pedro Cardim, Claúdia Castelo, Marta Lourenço, Vítor Rosado Marques, Ricardo Moreira and the editors of the special issue, Jenny Bangham, Emma Kowal and Boris Jardine, read earlier versions and provided insightful comments and corrections. Thanks finally to the anonymous reviewers of BJHS Themes for their important comments. All remaining imperfections are my responsibility. All translations from Portuguese into English are mine. This research has benefited from the use of the infrastructure of PRISC (Portuguese Research Infrastructure of Scientific Collections). 
anthropological sciences and the lives of their human keepers and users. To ask 'how collections end' is to ask also how collections endure, and how they fail to endure. Collections can reach an end, I hypothesize here, when they cease to give flesh to, or cease to become agents of, forms and conceptions of historical time. Thus conceived, scientific collections - including collections that encapsulate histories of colonialism and racialism - can reveal considerable resilience. In recent years, interest in the problem of historicity/ies has increased in history and anthropology. Historians of science and medicine are calling attention to how biomaterials obtained in the colonial era articulate time in different ways and forms: in associated archival documentation, in technologies of cryopreservation, in narratives of colonial violence and repatriation, or in distinct ethical regimes and varied (and sometimes conflicting) scientific and indigenous post-colonial reuses. ${ }^{1}$ Signalling the 'question of temporality', Emma Kowal, Joanna Radin and Jenny Reardon have called attention to the unintended 'mutating temporalities' of collections, associated with scientific practices and freezing technologies. ${ }^{2}$ These anthropological and science-studies concerns relate (although not always explicitly) to reflections on the persistence of imperial formations in colonial studies. In this field, a critical history of imperial 'legacies', or a 'reflexive anthropology' of the 'modes of presence of the [colonial] past', is also gaining traction. ${ }^{3}$ Engaging with the notion of ruin, for instance, Ann Laura Stoler prompted scholars to address the durability of imperial and racial regimes by turning attention to 'what remains ... to the material and social afterlife of structures, sensibilities, and things', and the ways people 'live with' the vestiges that colonial empires have left behind. ${ }^{4}$

This article extends this scholarship to propose a way of seeing a trace of Portuguese imperial science - approximately 16,000 dry samples of indigenous blood on paper cards collected during field expeditions in the 1950s - as a colonial 'chronotope'. ${ }^{5}$ In the humanities and social sciences the term 'chronotope' was first given wider application as a metaphor for time-space connectedness by literary scholar Mikhail Bakhtin. ${ }^{6}$ Although the term was used originally in the study of literary phenomena, it can be

1 Compare, for example, Ricardo Roque, 'Stories, skulls, and colonial collections', Configurations (2011) 19, pp. 1-23; Jenny Bangham, 'Blood, paper and total human genetic diversity', Limn (2016) 6, at https:// limn.it/blood-paper-and-total-human-genetic-diversity, accessed 2 February 2018; Joanna Radin, Life on Ice: A History of New Uses for Cold Blood, Chicago: The University of Chicago Press, 2017; Joanna Radin and Emma Kowal (eds.), Cryopolitics: Frozen Life in a Melting World, Cambridge, MA: The MIT Press, 2017; Radin and Kowal, 'Indigenous blood and ethical regimes in the United States and Australia since the 1960s', American Ethnologist (2015) 42(4), pp. 749-765.

2 Emma Kowal, Joanna Radin and Jenny Reardon, 'Indigenous body parts, mutating temporalities, and the half-lives of postcolonial technoscience', Social Studies of Science (2013), 43(4), pp. 465-483. See also Amade M'charek, 'Race, time and folded objects: the HeLa error?', Theory, Culture and Society (2014) 31, 6, pp. $29-56$.

3 Benoît de l'Estoile, 'The past as it lives now: an anthropology of colonial legacies', Social Anthropology (2008) 16, pp. 267-279, 279.

4 Ann L. Stoler, 'Imperial debris: reflections on ruins and ruination', Cultural Anthropology (2008) 23(2), pp. 191-219, 194. See also Stoler, Duress: Imperial Durabilities in Our Times, Durham, NC: Duke University Press, 2016.

5 This number is an estimate based on preliminary information provided to the author by the Lisbon Museum of Natural History and Science.

6 Bakhtin's original notion was adapted from physics. Mikhail Bakhtin, 'Forms of time and of the chronotope in the novel', in Bakhtin, The Dialogic Imagination: Four Essays by M. M. Bakbtin, Austin: University of Texas Press, 1981, pp. 84-258. 
more widely explored as a metaphor for approaching time and space as a 'concrete whole'; here time is a fusion that 'thickens, takes on flesh' in material space and material objects. ${ }^{7}$ My formulation of the colonial chronotope emphasizes this fusion zone between narrative and materiality. I conceptualize the notion of the colonial chronotope as a plastic configuration of pasts, presents and futures of empire, race, science and coloniality that takes material existence in the form of 'scientific collections'. Thus conceived, colonial chronotopes constitute forms of temporality that exist in collections and in the people, institutions and imaginaries with which they become associated. Human actions and understandings shape these processes. But so too does the materiality of the collections. Hence a collection's colonial chronotope is not simply a function of the narratives, inscriptions, sensibilities and social relations that act on the materials, and to which the latter are connected over time. The materials that constitute the collections also act upon their spatiotemporal arrangements, and may co-produce their own chronotopes.

My history of the blood group cards is the story of collections that persisted whilst undergoing critical endings and changes in their associated temporal imaginaries and agencies - including in the materiality of the records themselves. I argue that the persistence of these collections is entailed in the persistence of a plastic and multiple colonial chronotope. Here, I regard the card collections as intrinsically chronotopic agents charged with conceptions, narratives, affects and imaginaries of time in connection to empire, race and science. At their origin, the blood group cards were time-spaces upon which colonial narratives of an imperial and 'multiracial' community were built, and also were agents imbued with the capacity to translate perceived primitive indigenous racial pasts into perceived futures of Portuguese imperial sovereignty and scientific modernity. The cards went on to become a multifaceted time-space of their colonial scientific condition. I intend to follow how the cards as colonial chronotope emerged, changed and endured over the decades - even as the Portuguese empire vanished and even as the theories, actors and institutions that were at their origin changed or even ended. In this process, the colonial chronotope did not simply die; instead, it underwent several mutations and became manifold. I also argue that the very sociomaterial historicity of the collections has been interfering with the colonial constructs in which they have been trapped for so long. The very physical intimacy of the researchers with the cards led to their 'contamination' in genetic terms and hence their contemporary obsolescence, but it also led to a complex configuration of blood, paper, words and DNA traces that introduce novel tensions in the colonial chronotopia of the collections. I thus conclude by suggesting that in embracing the 'contaminated' present of the blood archive - beyond fixation on the future and beyond impurity as a problem - one may pave the way to a critique of the cards as colonial chronotope, and point to an alternative postcolonial significance of the collections.

\section{Colonial chronotope}

'I felt the greatest joy when I saw the extensive and intensive researches ... that are being currently undertaken by the anthropological mission led by Mr. Prof. António de

7 Bakhtin, op. cit. (6), pp. 84-85. 
Almeida. The mission has assembled enormous and interesting materials.'8 Thus in 1954, upon his return from a brief visit to the Portuguese colony of East Timor, the influential physical anthropologist António Mendes Correia (1888-1960), president of the Junta de Investigações do Ultramar (JIU) (Overseas Science Research Board, formerly Junta das Missões de Investigações Geográficas e Coloniais, Board for Colonial Research and Geographical Missions, created in 1936), evaluated the achievements and future potential of the Timor anthropological mission, the fieldwork expedition headed by his pupil and fellow anthropologist, medical doctor António de Almeida (1900-1984). Almeida's field campaign in Timor was the final chapter in a series of similar state-sponsored 'colonial anthropological missions', including his own 'anthropobiological mission' to Angola. By the 1950s, the Portuguese colonial empire still included vast portions of land in continental Africa (Angola and Mozambique) and a few scattered colonial territories in Asia (East Timor, Goa, Macau) and West Africa (San Tome, Cape Verde, Guinea Bissau). In 1951 the Portuguese imperial government introduced rhetorical changes that eliminated references to 'colonies' and the 'colonial empire' with a view to conveying the idea of 'national integration'. Hence the former 'colonies' in Africa and Asia merely changed name and were reconceptualized as 'overseas provinces', integral to the Portuguese nation, in an attempt to rhetorically adjust to the new winds of post-war anti-colonialism.

The model of anthropological missions, first proposed by Mendes Correia (then professor of anthropology at Porto University) in the early 1930s (also presumably inspired by comparable contemporary anthropological 'missions' in French colonial Africa), was quickly embraced by the Portuguese imperial state. ${ }^{9}$ Between 1936 and 1960, anthropological missions were launched to Mozambique, Angola, Guinea Bissau and East Timor, with the official support of the JIU, the state department in charge of implementing the policy of 'scientific occupation' of Portugal's colonies during Salazar's fascist Estado Novo regime. With regard to the missions, Correia's hopes for the 'study of population and the future of [Portugal's] Overseas' concentrated on the quantity and quality of the anthropological collections obtained in the colonies and brought to Lisbon and Oporto for later study. ${ }^{10}$ Correia's praise of the collections and impending results of the Timor anthropological mission also extended to the many materials assembled by his acolytes in other colonies. With the support of the local colonial administrations, the field teams collected a multitude of data that they presumed had raciological significance: anthropometric measurements, anthropological photographs, blood group determinations, dermatoglyphs, psychotechnic questionnaires and a disparate array of archaeological,

8 António Mendes Correia, 'Um Mês em Timor: Palestras na Emissora Nacional, na Série “A Ciência ao Serviço da Humanidade" em 26 de Fevereiro, 5, 12 e 26 de Março, 2 e 9 de Abril de 1955', Boletim da Sociedade de Geografia de Lisboa (1955) 73(4-6), pp. 173-192, 179.

9 Léon Palès's mission anthropologique de l'Afrique occidentale française of 1945-1951 would be emulated by Mendes Correia as a model, in his later defence of the Portuguese expeditions. See A.A. Mendes Correia, 'O estudo das populações e o futuro do Ultramar,' Boletim da Sociedade de Geografia de Lisboa (1951) 69(7-8), pp. 1-28, 20.

10 Correia, op. cit. (9), p. 15. 
linguistic and sociocultural records on paper, tape and film, including 'prehistoric' chipped stones.

These materials cohered within Correia's wide-ranging research programme, originally grounded on the French tradition of anthropology after Paul Broca - an encyclopedic multidisciplinary inquiry into human (racial) diversity, under the command of physical anthropology. Correia's programme for research in the colonies encompassed physical anthropology, archaeology and ethnography, the last two as subsidiary disciplines of the first. Specifically regarding physical anthropology, Mendes Correia was oriented by a refashioned form of racial science that he titled 'anthropobiology'. ${ }^{11}$ Anthropobiology, he wrote in 1933, encompassed classical anthropometrics and racial taxonomy, but also research on 'other subjects of human biochemistry, constitutions and temperaments, the determination of the biological basis and activity of the different races, etc.' ${ }^{2}$ A compromise between 'old' techniques (such as anthropometry, which he claimed should not be abandoned) and novel research methods (such as blood group studies) was part of Correia's singular attempt to remain faithful to the tenets of racial taxonomy whilst also embracing emerging tendencies - a defensive reaction, perhaps, to the international trends in evolutionary theory and to the critiques of racial typology that were to lead to the 'new physical anthropology' in the 1950 s. $^{13}$ In fact, although Mendes Correia and the expeditions' leaders occasionally evoked human biology and discussed demography, evolution and variation, the anthropobiological science of the missions, stubbornly attached to nationalistic ideals of Portugal's imperial sovereignty, remained largely subsidiary to an old-style descriptive form of typological and ethnogenic inquiry.

Established in 1936 with the creation of the JIU, the colonial anthropological missions materialized a new 'soft' form of Portuguese imperial sovereignty based on the notion of 'scientific occupation'. ${ }^{14}$ The concept gained further geopolitical importance after the Second World War when Portugal's obstinacy to retain its colonies became increasingly contested internationally and, finally, became the object of military opposition by African liberation movements. Thus a blend of antiquated and more fashionable bioanthropological techniques, including anthropometry and blood group studies, composed the apparatus of the 'anthropological missions' in the 1940s-1950s. Yet these

11 Correia, op. cit. (8), pp. 19-20. See also António Mendes Correia, Introdução ao Estudo da Antropobiologia, Coimbra: Imprensa da Universidade de Coimbra, 1933. Correia was the first in Portugal (perhaps inspired by foreign uses) to apply this term which was later taken up by António de Almeida and his followers. It seems the expression was used internationally by the 1950 s, to refer to a form of anthropology concerned with the biological study of humans. The term today can still define a form of human biology or a 'branch of anthropology' that studies humans as a biological species in a wide sense (including genetics).

12 Correia, op. cit. (11), p. 18. He had rephrased this definition in the early 1950s: Correia, op. cit. (9), pp. 19-20.

13 For overviews see Peter T. Ellison, 'The evolution of physical anthropology', American Journal of Physical Anthropology (2018) 165, pp. 615-625; Michael A. Little, 'Human population biology in the second half of the twentieth century', Current Anthropology (2012) 53(S5), pp. S126-S138.

14 See Cláudia Castelo, 'Investigação científica e política colonial portuguesa: evolução e articulações, 1936-1974', História, Ciências, Saúde-Manguinhos (2012) 19(2), pp. 391-408. 
were, or were supposed to be, ultimately raciological inquiries. They were also inherently colonial and nationalistic knowledge endeavours, expressing a political investment in the maintenance and survival of Portugal's imperial grandeur in an age of growing anti-colonial and anti-racist ideologies. For their founding father, Mendes Correia, the missions were the ultimate incarnation of the principle of 'scientific occupation'. 'It is already commonplace', he stated in 1945, whilst explaining the rationale of the emerging state agenda of the anthropological missions, 'to affirm that after the political and military occupations it is indispensable to continue intensely in the scientific occupation of our colonies.' ${ }^{15}$ Anthropology field studies were a continuation of military and political occupation by other, scientific, means; consequently their resulting collections of data were the matter that made empire's sovereignty tangible and manifest. The missions were also a promise of biopolitical intervention. Studies of the racial diversity and biological vitality of indigenous peoples were intended to inform more efficient colonial administration of indigenous populations and a more productive 'use' of the 'natives' in the colonial labour economies. ${ }^{16}$

The colonial anthropologists' fixation with the 'enormous and interesting materials assembled' was important and recurrent - and this is a point I would like to emphasize. One reason for this was that the collections embodied certain visions of time, political sovereignty and epistemic prosperity with regard to science and empire. From the nineteenth century to the 1950 s, the ancient imperial past - the so-called glorious Age of Discoveries in the sixteenth century, when maritime ventures in Asia, Africa and the Americas placed Portugal in a singular position as a world power - was still referential to the Portuguese nationalist imagination, especially during Salazar's regime. ${ }^{17}$ As regards the missions, however, the primary reference was not the past, but a Portuguese empire to be realized in an immediate future through the agency of anthropological data extracted from the bodies of indigenous people. The anthropometric tables, photographs, blood group cards and so forth were seen as pathways to bio-anthropological knowledge about human ethnogenesis and diversity; they were also perceived as pathways to a multiracial community that, in the imperial nationalist credo, promised to eternize a glorious history of imperial prosperity and grandeur. ${ }^{18}$ Possessing such 'enormous and interesting materials' anticipated a golden age of empire and race science, a future the anthropologists prefigured in the paper, tape, film and material records of the expeditions.

The colonial anthropologists' triumphant visions of the present and future wealth of the assembled data revolved strongly, though not exclusively, around the card samples of

15 Mendes Correia, ‘Missões Antropológicas às Colónias', Jornal do Médico (1945) 7(149), pp. 3-10, 3.

16 Mendes Correia, Plano de Estudos Antropológicos Coloniais, 12 March 1941, Lisbon, Arquivo Histórico do IICT/Universidade de Lisboa (hereafter AHIICT-UL), Espólio das Missões Antropológicas, Processo 150.

17 Portuguese scholarship on the topic is considerable but see, for example, Maria Isabel João, Memória e império: comemorações em Portugal (1889-1960), Lisbon: Fundação Calouste Gulbenkian, 2002.

18 See Ricardo Roque, 'The racial science of patriotic primitives: António Mendes Correia in Portuguese Timor', in Warwick Anderson, Ricardo Roque and Ricardo Ventura Santos (eds.), Luso-tropicalism and Its Discontents: The Making and Unmaking of Racial Exceptionalism, Oxford: Berghahn, 2019, pp. 159-183. 
ABO blood groups. Serology, which by the 1950s was considered a promising complementary method for discriminating affinities and differences among human races, figured importantly in the field methods of the missions. First established in the early 1900 s, the classification of human blood types into A, B, AB and O (known as the $\mathrm{ABO}$ system) dramatically expanded the clinical uses of blood transfusion, and came to configure one of the first applications of the principles of Mendelian genetic inheritance in humans. Anthropologists soon applied serological methodologies and categories to racial analysis. ${ }^{19}$ Like his anthropological counterparts in Europe and the US, Mendes Correia regarded serology as a valid procedure in the study of human races and incorporated it into the constitutive paraphernalia of colonial anthropobiology: 'meanwhile, it is valid today', he declared in 1933, 'to ground upon the knowledge of blood groups a new aspect of the study of constitutions and races'. ${ }^{20}$ In Europe and elsewhere, serological literature on the connections between blood types, race and nationality grew exponentially in the interwar years fed by the winds of nationalism and scientific racism. ${ }^{21}$ After the Second World War, blood group research continued to grow. National blood transfusion services expanded whilst the collecting and study of human blood attracted new international biological research on human diversity, evolution and variability. In the 1950s, for example, whilst the last mission to Angola and the first Timor anthropological mission were launched, interest in blood group distributions was at an international peak. ${ }^{22}$ Massive blood collecting from remote or so-called 'primitive' indigenous peoples also became globally significant in the light of emerging human biology programmes of biomedical research, evolutionary theory, ecology and early genetics research in the post-war era. ${ }^{23}$ Hence in the 1950 s-1970s context,

19 See Jenny Bangham, 'Blood-groups and the rise of human genetics in mid-twentieth-century Britain', PhD dissertation in history of science, University of Cambridge, 2014; Bangham, 'What is race? UNESCO, mass communication and human genetics in the early 1950s', History of the Human Sciences (2015) 28(5), pp. 80-107.

20 Correia, op. cit. (9), p. 31.

21 'The anthropological uses of the serological discoveries began in most countries', writes Schneider, 'as an effort to find a more "scientific" definition of race based on differing distribution of blood types.' See William Schneider, 'Blood group research in Great Britain, France, and the United States between the World Wars', American Journal of Physical Anthropology (1995) 98(4), pp. 87-114, 87. See also Pauline Mazumdar, 'Blood and soil: the serology of the Aryan racial state', Bulletin of the History of Medicine (1990) 64, pp. 187-219. Jennifer Robertson, 'Hemato-nationalism: the past, present, and future of “Japanese blood”', Medical Anthropology (2012) 31(2), pp. 93-112.

22 On the global significance of blood group research in this period compare Jenny Bangham, 'Blood groups and human groups: collecting and calibrating genetic data after World War Two', Studies in History and Philosophy of Biological and Biomedical Sciences (2014) 47, pp. 74-86; Elise Burton, 'Essential collaborators: locating Middle Eastern geneticists in the global scientific infrastructure, 1950s-1970s', Comparative Studies in Society and History (2018) 60(1), pp. 119-149; Projit Mukharji, 'From serosocial to sanguinary identities: caste, transnational race science and the shifting metonymies of blood group B, India, c.1918-1960', Indian Economic and Social History Review (2014) 51(2), pp. 143-176.

23 See Susan Lindee and Ricardo Ventura Santos (eds.), The Biological Anthropology of Living Human Populations: World Histories, National Styles, and International Networks, special issue of Current Anthropology (2012) 53(S5); Jenny Bangham and Soraya de Chadarevian (eds.), Human Heredity after 1945: Moving Populations Centre Stage, special issue of Studies in History and Philosophy of Biological and Biomedical Sciences (2014) 47. 
although largely isolated from these global programmes and framed by pre-war notions of race and 'old' physical anthropology, the massive biodata on the empire's 'indigenous tribes' extracted by the Portuguese expeditions may have come to unintentionally fit in the international value then granted to blood and other biodata from 'primitive' indigenous peoples.

Between the 1940s and 1960, colonial blood collecting in the Portuguese empire was in its heyday. Fieldwork campaigns in the Portuguese colonies resulted in 'thousands of observations on individuals of varied tribes' obtained in situ in the form of fresh samples, but also obtained in the form of individual 'Sanotest' paper cards. A drop of blood from an indigenous donor and anti-sera for $\mathrm{ABO}$ determination were mixed together on the card, their patterns of agglutination revealing the blood group of the source. The blood was collected on cards in accordance with categories of 'tribes' or (increasingly from the early 1950s) of so-called 'ethnic' or 'ethno-linguistic groups'. In post-war physical anthropology, partly in reaction to the association of 'race' with 'racism', the term 'ethnic group' was then used as either subsidiary to, interchangeable with or even a replacement for the notion of 'race'. ${ }^{24}$ Similarly, in the 1950s and beyond, the Portuguese anthropobiologists' extensive use of the notion of 'ethnic group' in collecting, arranging and classifying the blood samples became a proxy for 'race'. Hence the cards containing dried blood/sera cohabited with 'ethnic group' categories, the name of individuals and the classification of blood groups. In contrast with other blood collecting programmes around the same historical period (especially from the late 1950s), the fresh samples extracted in the expeditions were not preserved as collections; only the paper cards with dried blood for $\mathrm{ABO}$ blood group determination were kept. ${ }^{25}$

The use of cards allowed quick mass collecting of blood group results in the field, whilst offering easily transportable and manageable samples for later laboratory classification and statistical analysis. ${ }^{26}$ By the late 1950s, except for the missions in Mozambique (where a different collecting method of ABO blood groups was followed), the number of card samples amounted to around seven thousand from Angola and seven thousand from Timor, perhaps five hundred from San Tome and 1,400 from Guinea Bissau, and a few hundred more from Macau. In contrast with fresh samples, blood cards could be accumulated, stored and manipulated as small paper files for further statistical and classificatory analysis, without the need to resort to complex and expensive refrigeration technologies. Consequently, human blood literally became a paper archive.

Blood cards stood out as material embodiments of the promises of colonial race science. They encapsulated an imaginary of political possession and epistemic value, propelling Portuguese imperial and scientific temporalities towards the future. Like many anthropological collections, colonial collections of blood cards were viewed as

24 See, for example, 'Statement on race: Paris July 1950', in Four Statements on the Race Question, Paris: UNESCO, 1969, pp. 30-36.

25 In fact collections of blood samples began only in the late 1950 s, when serum proteins could be analysed from these (blood groups could only be tested on fresh blood, because freezing ruptured the red cell membranes). I thank Jenny Bangham for this information.

26 On the expeditions' blood-collecting technologies see Ricardo Roque, 'Bleeding languages: blood groups and linguistic ontologies in East Timor', MS in preparation. 
containers of knowledge about indigenous races conceived of as timeless primitives. ${ }^{27}$ They ideally gave access to human bio-ethnic pasts. They were also time-travelling devices in another sense. Were their secrets properly possessed, curated and decoded by Portuguese anthropologists, blood paper cards could allow Portuguese colonial science to align with the modern scientific present, whilst at the same time infusing vitality in the colonial empire, embattled as it was against the hostile post-war anti-colonial world. In the 1950s-1960s, therefore, the epistemic and political potency of the missions' collections, such as the blood cards, was understood in relation to certain conceptions of time that coalesced expectations of scientific and imperial future with racialized imaginaries of indigenous primitivism. At the junction of these imaginaries, the collections constituted a multidimensional colonial chronotope that could at once deliver colonial scientists into 'generalized past worlds' in racial-biological time, ${ }^{28}$ and send them to abstract present and future worlds of imperial sovereignty and epistemic prosperity.

\section{The society of blood cards and anthropologists}

The blood card collections became intimately linked to the life of António de Almeida, his close associates and the scientific institution under his tutelage since his return from the expeditions in the 1950s. In Lisbon, his colonial collections became the most important building block of a social community of scientists devoted to the study of overseas populations, under the premises of the scientific discipline of anthropobiology. In the early 1950 s, the political proximity to the fascist regime and the proclaimed 'success' of the anthropological missions (success judged by the quantity of assembled data) strengthened the political and scientific authority of Almeida, the leader of the Angola and Timor missions (and also of the San Tome Ethno-sociology Brigade). Since 1935 he had been the chair of colonial ethnology and ethnography at the High Colonial School in Lisbon; he was also, like Correia, an engaged political actor, a deputy to the National Assembly (1938-1957); in 1955 he was appointed director of the new Centro de Estudos de Etnologia do Ultramar (CEEU) (Centre for Overseas Ethnology Studies) that was established in association with the High Colonial School and the Overseas Science Board, to satisfy his demands. The centre was primarily created to guard, curate and study the vast collections assembled by Almeida's anthropological missions in Timor and Angola: 'the elements for study already collected or to be collected are multiple and important', wrote Mendes Correia, by then also president and director of the High Colonial School, in an official letter of 1951 that justified the need to create this research centre: 'Their number is so high that they cannot be studied and published by that professor [Almeida] alone; instead they constitute the task for a team of several researchers. ${ }^{29}$

27 See Joanna Radin, 'Latent life: concepts and practices of human tissue preservation in the International Biological Program', Social Studies of Science (2013) 43(4), pp. 483-508.

28 Stephan Palmié and Charles Stewart, 'Introduction: for an anthropology of history', Hau: Journal of Ethnographic Theory (2016) 16(1), pp. 207-236, 219.

29 Mendes Correia to Director General of Ministry of Overseas, 3 February 1951, AHIICT-UL, Processo 437, Centro de Estudos de Etnologia do Ultramar, vol. 1 (1948-1958). 


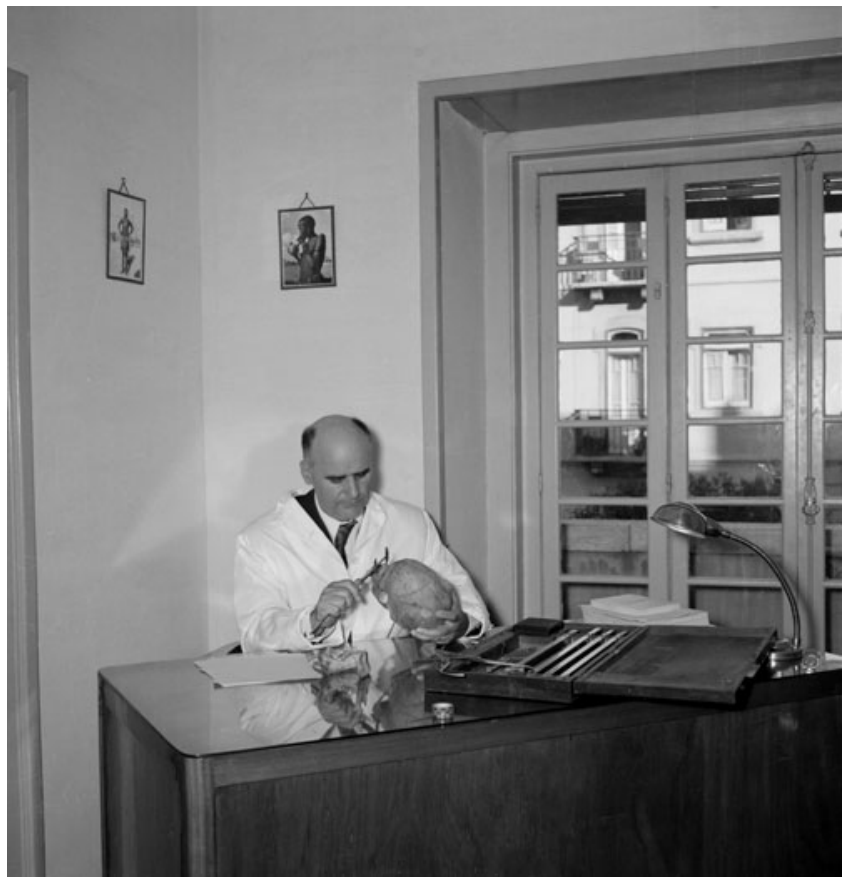

Figure 1. Anthropobiologist António de Almeida, measuring a human skull at the Centre for Overseas Ethnology Studies in Lisbon, in 1958. Photographer unknown. Photography Collection, Tropical Research Institute (IICT), University of Lisbon. Ref. INV. ULisboa_IICTIICT21937. With permission of MUHNAC/ULisboa.

The need for a collective of scientists to care for and study the collections justified the creation of a new scientific institution (the CEEU), founded in 1954 by decree of the Ministry of Overseas, that in turn defined the small community of anthropobiologists. ${ }^{30}$ As such the samples and their colonial chronotope became central to the institution, and to the identity and purpose of Portuguese anthropobiology. Scientists, hence, were expected to devote themselves almost exclusively to the perpetual care of the samples and the extraction of their hidden powers. Some years later, in 1962, in a context of disciplinary redefinition within the JIU, the CEEU was renamed the Centro de Estudos de Antropobiologia (CEA) (Centre of Anthropobiology Studies), allegedly to clarify its 'anthropobiological' identity and distinguish itself from a new Centre of Cultural Anthropology Studies, then created under the direction of cultural anthropologist Jorge Dias. Besides the director, Almeida, the CEEU/CEA staff was composed of a handful of full-time researchers and technicians (never exceeding a half-dozen), and a larger transient network of part-time researchers and external collaborators based at

30 Francisco da Cunha Leão, on the creation of the CEEU, 10 February 1951, AHIICT-UL, Processo 437: Centro de Estudos de Etnologia do Ultramar, vol. 1 (1948-1958); Sarmento Rodrigues, Minister of Overseas, Portaria no 14 886, 15 May 1954. 
Lisbon (where the centre was founded) and Porto University (the institutional birthplace of Mendes Correia's colonial anthropology).

Work began almost immediately after the centre was created, first in provisional rooms in the High Colonial School and, finally, from April 1956 (and until 2004), in a large rented apartment in central Lisbon. The flat (originally for housing purposes) was adapted to accommodate research offices and to house the prehistoric and anthropobiological materials. It was in this foundational period that the blood cards were archived in a wooden cabinet, acquired in 1957 and made especially for the purpose of storing the blood group files. ${ }^{31}$ The organization of cards combined a colonial geography of 'overseas possession' with a racialized order of 'ethnic group'. The cards were ordered in drawers labelled with the place name of the colonial territory and, in some cases, the name of certain ethnic groups. Within each drawer, the cards were organized by 'ethnic group'.

The CEEU/CEA did not promote new fieldwork expeditions in the manner of the 1940s-1950s campaigns of the anthropological missions. It was, above all, a museum-laboratory where collections and field data were to be curated, classified and analysed by their resident anthropobiologists. Almeida was the director until his retirement in 1970; retired, he continued to exert strong influence on the destinies of the centre. For decades he dominated the institution, and kept strict control over access to the missions' collections until his death. Whilst at the centre, he maintained an almost exclusive personal right to access and use the expeditions' records from Angola and Timor especially. He transferred this exclusive right to his daughter, and later, as we shall see, the same sort of right was claimed and preserved by incoming CEA staff until the centre's late extinction.

The affections and chronotopic imageries that anthropobiologists imbued in the collections proved to be a driving force of CEA activity. From 1954 onwards, 'urgency' and 'great importance' were terms used frequently by both Almeida and his institutional superiors with regard to the centre's primary objective: to continue 'the statistical study of the many thousands of meristic [quantitative] data collected from natives in Angola, Timor and San Tome and the abundant prehistoric material'. ${ }^{32}$ Almeida's accounts of participation in international congresses consistently reported that foreign anthropologists working on Pacific materials were impressed by the extent of the data obtained in the Portuguese field missions and the comprehensiveness of the series on blood

31 Mapa de Cadastro enclosed in Director CEAB to Direcção-Geral do Património, 31 December 76, AHIICT-UL, Processo 292, Centro de Estudos de Antropobiologia, vol. V (1976-1977).

32 António de Almeida to Director of ISEU, 22 March 1955, AHIICT-UL, Processo 437, Centro de Estudos de Etnologia do Ultramar, vol. 1 (1948-1958). See also Informação JIU no 221/437/56, 25 July 1956, AHIICTUL, Processo 437, Centro de Estudos de Etnologia do Ultramar, vol. 1 (1948-1958). Significant archaeological collections - also aimed at complementing physical anthropology with evidence on the deep pasts of indigenous populations - were obtained during the missions in Angola, Timor and Mozambique. The analysis of these collections and their significance, however, is beyond the scope of this paper. But see Rita Juliana Poloni, 'Expedições arqueológicas nos territórios do Ultramar: uma visão da ciência e da sociedade portuguesa no período colonial', $\mathrm{PhD}$ dissertation in archaeology, University of Algarve, 2012. 
groups. ${ }^{33}$ In the 1950 s and 1960 s, international interest in the scientific potential of the missions' records nurtured the current investment of many human biologists in collecting and mapping the geographical distribution of human blood groups. ${ }^{34}$ But Almeida's celebratory statements concerning international interest in the samples should be read with caution. They were arguably aimed at a Portuguese audience with a view to solidifying Almeida's scientific authority internally and accruing the urgency and value of his endeavour before his superiors and state funders. In a historical context in which Portugal and its imperial ambitions were criticized internationally, such statements bearing evidence of Portugal's achievements in ongoing scientific occupation in the colonies - also carried a political message against real or imaginary, and internal and external, detractors of Portuguese colonialism. In any case, António de Almeida held on to the belief in the inherent present and future value of the blood group archive, hoping the secrets it contained would contribute significantly to international debates and align Portuguese colonial anthropology with foreign science and modern times.

Almeida grounded his, and his centre's, scientific authority upon the possession and continuing exploitation of the collections, reinstating the collections' condition as colonial chronotopes of future knowledge and imperial sovereignty. He argued that the data they contained demonstrated the success and international recognition of Portuguese anthropobiology and their contribution to a 'multiracial' national empire. But, beyond these imaginaries, concrete scientific outputs from the data were also required. From the blood cards, he intended to draw general conclusions and generate substantive knowledge. However, the cards' capacity to bring forth a bright future of revelations seemed to be constantly postponed. Over the years, Almeida and his associates struggled to coherently organize and fully study the vast mass of archaeological, linguistic and biological data collected in the 1940s and 1950s. Concerning the blood records in particular, notwithstanding repeated reference to 'continuing work', the final results were slow to appear. Throughout the 1950s-1970s, several case study articles on different 'ethnic groups' (from Angola and Timor in particular) were published (predominantly in Portuguese and French) as pieces of a totalizing project that promised a synthetic and comprehensive treatment of all the blood group data. Almeida especially aimed at completing the Ethnic or Anthropological Chart of 'Portuguese Timor' whilst also producing a special study of the 'primitive' Angolan Bushmen. To this purpose Almeida did not work alone. He shared the study of the ABO blood group records with his daughter, Maria Emília Castro e Almeida (1929-2007), who ultimately took on the bulk of the statistical labour and, finally, the credit for analysis and publication.

Almeida hired his daughter as a researcher in the centre under his direction as soon as she finished her degree in biology at the University of Lisbon in the early 1950s. He eventually proposed that she focus on the sero-anthropology of the vast $\mathrm{ABO}$ blood group data from his Angola and Timor campaigns, perhaps in the expectation that she would build her career upon this unique data set. Young Castro e Almeida accompanied

33 See António de Almeida to President of Comissão Executiva JIU, 28 March 1967, Lisbon, Arquivo Histórico Ultramarino, Processo Individual de António de Almeida, Livro III (1966-1967).

34 See Bangham, op. cit. (22); Burton, op. cit. (22); Mukharji, op. cit. (22). 
her father on his last campaign to Angola and on their return she contributed to the work of organizing, archiving, classifying and computing the $\mathrm{ABO}$ data along ethno-linguistic distributions. She went on to study biological statistics at Porto University under physical anthropologist Alfredo Athaíde; she then went to Paris, to work with Belgian biologist and anthropologist Jean Hiernaux, who eventually co-supervised her (unfinished) $\mathrm{PhD}$ thesis on the Fataluku of East Timor.

When Almeida died in Lisbon in 1984, leaving his final synthetic work incomplete, Maria Emília became the designated heir to his work and visions on anthropobiology, to the direction of the centre, and to his possessive and affective attachment to the colonial biological data - that 'great and rich scientific estate', in her own words, collected by her father in the overseas missions and which, as late as 1994, she described 'as a scientific trove of great value, still in the present'. ${ }^{35}$ She cared for the collections as she cared for the posthumous memory of her late father, periodically republishing his work, and forever lamenting the mistreatment of his achievements by the new generation of social and cultural anthropologists of the post-April revolution era. ${ }^{36}$ For three decades, the card collections assembled by the anthropological missions became continuous with both her scientific and her personal identity.

First under her father's instruction, and then alone in the Centre of Anthropobiology, she became the sole keeper, carer and user of the blood card archives until she retired in the early 2000s. Between 1954 and 1982, she worked wholeheartedly on the analysis and statistical treatment of the cards. Among her first publications in the 1950s are a number of articles on the $\mathrm{ABO}$ blood groups of Angolan 'tribes', the Macanese and the Timorese co-authored with her father. In the 1960s-1970s she published sequences of separate case studies on blood frequencies in Angolan tribes and on the distribution of Timor's ABO blood groups among distinct ethno-linguistic groups. At last, after a slow path to publication, a monograph compiling her painstaking calculations of distributions of blood groups in East Timor, based mostly on the colonial samples, appeared in 1982. This was a dry, descriptive serological Portuguese monograph of 150 pages, presented as a contribution to the 'knowledge of human variability' based on the 'ABO system'. ${ }^{37}$ The Timor monograph, however, was presumably Castro e Almeida's definitive work on the blood group archive. By the time it was published, however, times had changed dramatically for the empire and the science they stood for.

In the 1980s, the early promises of sero-anthropology were considered out of date by many human biologists; by the 1990s they had been superseded by DNA studies and the

35 Maria Emília Castro e Almeida, 'Prefácio', in António de Almeida, O Oriente de Expressão Portuguesa, Lisbon: Fundação Oriente, 1994, pp. 7-8, 7. In 1994, almost a decade after his death, Castro e Almeida and her colleagues at CEA compiled and published posthumously a number of António de Almeida's research articles. See António de Almeida, Os Bosquimanos de Angola, coord. Maria Emília Castro e Almeida and Maria Cristina Neto, Lisbon: IICT, 1994; Almeida, O Oriente, op. cit.

36 On 25 April 1974 a democratic revolution put an end to the Estado Novo and its colonial empire. In the new democratic regime, 'social and cultural anthropology' achieved growing institutional recognition in university courses. See, for example, Susana de Matos Viegas and João de Pina-Cabral, 'Na encruzilhada portuguesa: a antropologia contemporânea e a sua história', Etnográfica, (2014) 18(2), pp. 211-332.

37 Maria Emília Castro e Almeida, Estudo Serológico dos Grupos Etnolinguísticos de Timor-Díli: Sistema (ABO), Lisbon: Instituto de Investigação Científica Tropical/Junta de Investigações do Ultramar, 1982. 
methods of modern laboratory genetics. The 1970s-1980s were also challenging political times for the scientific community of anthropobiologists and the collections at the CEA. In April 1974, a democratic revolution in Portugal finally put an end to decades of fascist dictatorship and, following the terrible years of colonial/liberation wars, the new Portuguese government granted Angola, Mozambique, San Tome, Cape Verde and Guinea Bissau the national independence they had demanded since the early 1960s. A fast process of decolonization followed, culminating in the end of the Portuguese colonial empire. At home, though, the end of empire led the Portuguese government to reform the former scientific research system only slowly and tentatively. The Overseas Science Research Board, until then entirely dedicated to the study of the overseas possessions, lost its former lustre and changed its name, but did not disappear or lose the core of its scope and attributions. After the revolution the former JIU (Overseas Science Research Board) was slowly modified only on the surface; it was finally renamed the Instituto de Investigação Científica e Tropical (IICT) (Tropical Sciences Research Institute) in 1983 and became a national state laboratory. For the next forty years the IICT remained a state-funded scientific laboratory, but it entered a long, difficult and ultimately failed adjustment to the post-colonial landscape of democracy and decolonization. In this context, until the refounding of the CEA as an autonomous research unit of the IICT in 1983, the centre experienced institutional subalternity and a threatened existence. ${ }^{38}$ The retirement of António de Almeida in 1970 was followed by internal turmoil concerning the destiny of the centre and its collections. The CEA became divided into prehistory and anthropobiology sections, and the group of anthropobiologists, headed by Castro e Almeida, became subordinate to the authority of archaeologist Miguel Ramos, the new director, for almost a decade.

Until his death in 1984, Almeida's power claims on the centre's collections were recurrent. In early 1974, for instance, he attempted to take private possession of the physicalanthropology archives of the anthropological missions for himself. He wrote to the JIU authorities requesting permission to move, either to his own house or to his office at the Lisbon Geographical Society,

the anthropological and ethno-historical materials collected by the official missions under my leadership and in other research trips in Portugal's Overseas, including the cabinets, bookcases and other files in which they are currently stored, so they are more easily manipulated [by myself] for the purpose of elaborating new works. ${ }^{39}$

This request denied, the collections remained at the CEA and there - except for the prehistoric materials - they continued firmly under the thumb of Almeida's daughter. Henceforth, at the CEA, a centre permanently underfunded and understaffed, the

38 In 1973 a decree reforming the JIU (then renamed Junta de Investigações Científicas do Ultramar (JICU)) decided on the extinction of the CEA and its incorporation in a wider so-called 'Centre of Studies on Anthropological Sciences' (Centro de Estudos de Ciências Antropológicas). This determination, however, was pending until at least 1977; with the creation of the IICT in 1983, the latter centre would not be created and the CEA preserved its institutional identity. Decreto-Lei 583/73 of 6 November, at https://dre. tretas.org/dre/229620/decreto-lei-583-73-de-6-de-novembro, accessed 4 February 2018.

39 António de Almeida to Director of Centre of Anthropobiology, 29 January 1974, AHIICT-UL, Processo 292, Centro de Estudos de Antropobiologia, vol. IV (1974-1975). 
meaning and value of the collections became increasingly overdetermined by the temporally and politically distant past of the colonial expeditions. Imprisoned by the expeditions' colonial heritage, the Centre of Anthropobiology and its staff survived in the margins of the national scientific system. This was a peripheral position reinforced by anthropobiology's uncomfortable and discordant place in the configurations of the anthropology discipline that gained force with the rise of a new generation of sociocultural anthropologists in the post-April Revolution period. The sociocultural anthropology coming into its own since the 1970s forged its disciplinary identity in opposition to the forms of 'anthropo(bio)logy' represented by Almeida and associated with the former fascist and colonial regime of the Estado Novo. ${ }^{40}$

In 1992, the centre was reduced to three researchers - Maria Emília Castro e Almeida (director), Maria Cristina Neto and Vítor Rosado Marques - supported by one administrative assistant and one technician. The situation did not improve for the remaining twelve years of the centre. ${ }^{41}$ Castro e Almeida, however, never turned her back on the overseas collections and the dictates of human biology and post-war physical anthropology. At her CEA office in Lisbon, then as director of the centre, her bond to her father's legacy and the archives of the expeditions developed into a personal cause, an exclusive affective possession, and an ultimately unfinished doctoral project. ${ }^{42}$ In 2004, as the IICT struggled to reform its own institutional colonial chronotope, the centre (by then restricted to biological anthropology) was extinguished as an autonomous unit. The records from the anthropological missions were dispersed through the institute's many facilities in the Alcântara-Belém area of Lisbon. By then, Castro e Almeida had already retired. She passed away in Lisbon in 2007. The cards seemed certain to become a relic of colonial science, mere remains of an imperial formation. Nevertheless, both the physical existence and the chronotopic potency of the cards endured. After Castro e Almeida retired, on the institutional margins of the IICT, the collections were preserved by the last of the anthropobiologists, who kept the hope of the collections' present significance and scientific future alive. At the CEA the question grew ever more urgent: how to live with the collections and remain faithful to their promise when the imperial source of this promise was considered by almost everyone to be extinct? The socio-institutional assemblage of scientists and blood cards declined after the 1970s-1980s and came to an end in the 2000s. Without this socio-institutional assemblage in place, what past, present and future could the collections deliver? Amidst all these ends, what can we learn about the conditions of possibility that facilitated the blood cards' duration as a colonial chronotope?

40 See João de Pina-Cabral, Os Contextos da Antropologia, Lisbon: Difel, 1991, pp. 11-41.

41 'Centro de Antropobiologia', in Anuário de Actividades 1992, Lisbon: IICT, 1993, pp. 257-259.

42 For reasons unknown, Maria Emília Castro e Almeida never finished writing her planned doctoral dissertation on the Fataluku people of East Timor. 


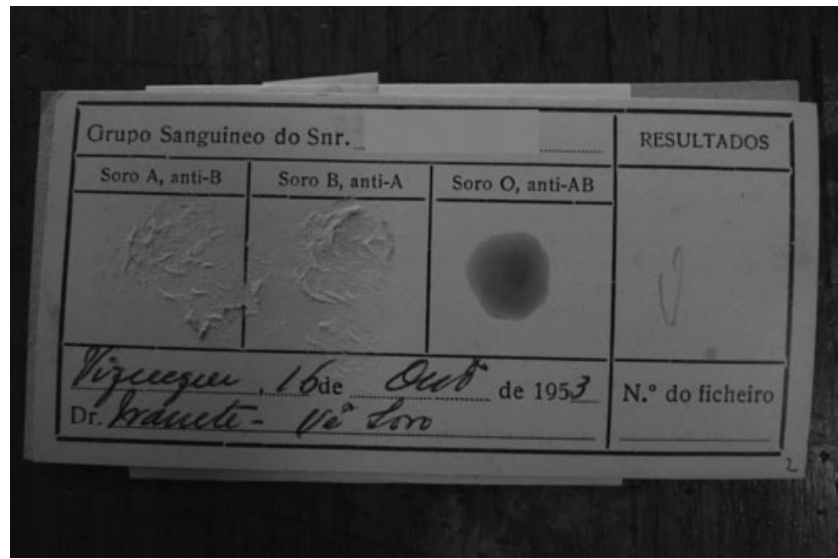

Figure 2. Blood group card from the Timor anthropological mission of 1953, showing traces of scratching and removal of blood samples for the purposes of genetic analysis fifty years later. This is presumably one of the cards borrowed by geneticists for a trial of DNA extraction, and afterwards returned to the collections in Lisbon in the 2000s. Photograph by the author, April 2013. Donor name anonymized by the author. Collection of Anthropology/Blood Samples, Tropical Research Institute (IICT), University of Lisbon. With permission of MUHNAC/ULisboa.

\section{The future that never was}

In 2013, Vítor Rosado Marques - the last staff researcher of the former Centre of Anthropobiology still active at the Tropical Sciences Research Institute (all his former colleagues having either retired or died) - recalled to me his years as lonely carer of the biological collections of the colonial anthropological missions. ${ }^{43}$ We both stared at the wooden filing cabinet where the blood group cards were originally stored and archived by Almeida and Castro e Almeida in the 1950s. As the conversation unfolded, it was hard not to share Marques's feeling of institutional abandonment and carelessness as regards the materials. We were in a secluded back office in one of the IICT's many dispersed facilities, which, at the time, served as an improvised storeroom for the remains of the extinct centre: furniture, stationery, publications, posters, manuscripts, assorted stuff and boxes from the old colonial missions and, in a corner, the cards cabinet. In the mid-2000s all these various materials had been moved from the facilities of the former CEA at Av. Óscar Monteiro Torres, into this back room at Junqueira Street, in Lisbon, by order of the IICT presidency, but they were never the object of further special measures. They simply lay there.

Rosado Marques struggled against the ongoing obsolescence of the archive. For Marques, this was not waste; these were things to live with, and things worth living

43 By then Rosado Marques was head of the Department of Human Sciences of the IICT. With Ana Cristina Roque, Marques and I had recently finished our collaboration as co-organizers of the Timor: Missões Científicas e Antropologia Colonial symposium held in Lisbon in 2011. This and the following references to Vítor Rosado Marques are based on my notes from several informal interviews and conversations held over the years, especially in 2013 and 2017. 
for. They held a creative scientific power. Rosado Marques graduated in biology from the University of Lisbon in 1986 and joined the Centre of Anthropobiology to work on human population anthropometrics. He was soon inculcated into the cards' promised value. He witnessed the intimate bond between Castro e Almeida and the files, which he had been allowed to approach only from a distance until she left the academic scene. 'We had conversations about it', he recalled, but that was her very 'personal project'. After Castro e Almeida's retirement, Rosado Marques tacitly took on the position of single carer, user and gatekeeper of the blood group cards archive; for some time he even continued Castro e Almeida's project on the Timor records. 'It was there, next to me', he remarked; the archive was a 'moral obligation'. Marques took over Almeida's task; he became heir to the attachment that his senior colleague had nurtured with regard to her father's collections.

When I first met Rosado Marques back in 2001 in his office at the old Centre of Anthropobiology - a 1950s flat packed to the roof with dusty publications, post-war furniture and an incalculable variety of field records and samples from the anthropological expeditions (bones, films, recordings, cards and so forth) - he was already the lonely user and gatekeeper of the blood archive. Twelve years later, as he shared his dismay with me, much had changed. The 2000s were times of turmoil and uncertainty at the IICT for the few anthropobiologists still employed at the centre, including Rosado Marques. ${ }^{44}$ In 2004, the IICT underwent a major reform under the presidency of Jorge Braga de Macedo, a neo-liberal economist and former politician and minister of finances. Since at least the 1990s, the IICT was perceived, in Macedo's words, as a 'dead institution, with old people, uninteresting', in stark contrast with the growing internationalized Portuguese system of science and technology that flourished under the dynamic Minister of Science José Mariano Gago. ${ }^{45}$ Macedo took it upon himself to rebrand the IICT and rehabilitate its weighty colonial past. He intended to transform the IICT from an institution oriented to its glorious past - in his own words, without 'direction', 'curved under the weight of its history and heritage' - to a new forward-looking organism focused on applied research, economic cooperation, foreign-affairs policies and ideals of development. The former Portuguese colonial territories and populations continued to be the privileged focus of research and intervention. The purpose now was to maintain and renew a clear 'lusophone mission' - that is to say, a political and scientific focus on Portugal's former imperial possessions, now rephrased as 'tropical' lusophone countries. ${ }^{46}$ To project the institute into the future was also to revalue and give new meanings to its colonial past and so-called accumulated 'tropical knowledge' (saber

44 The tumultuous existence of the CEA in this period perhaps bears contrast with the institutional assertion of biological and forensic anthropology in Portuguese universities. This recent history of biological anthropology, however, is yet to be studied in detail.

45 'Interview with Professor Jorge Braga de Macedo, president of IICT Tropical Research Institute of Portugal', Vegamedia/Business Week, 19 October 2006, at www2.iict.pt/archive/doc/BusWeek_jbmInterview.pdf, p. 2, accessed 2 February 2018.

46 'Entrevista ao Professor Doutor Jorge Braga de Macedo, Presidente e Responsável pelo Programa de Desenvolvimento Global do IICT, 5 Janeiro 2007', in Sofia Lopes (ed.), 3 Anos pela Renovação do Instituto de Investigação Científica Tropical, Lisbon: IICT, 2007, pp. 21-22. 
tropical), stimulating a kind of neo-luso-tropicalist form of engagement with the nations that had been Portugal's former colonies, now conceived as a 'community of Portugueselanguage countries' (comunidade dos países de língua portuguesa - CPLP). ${ }^{47}$ In this context, the fate of the colonial collections came into question.

Macedo envisioned a reinvention of the colonial 'legacies' of the institute as 'scientific heritage' of a common lusophone world. Within the framework of lusofonia, Portugal, Angola, Mozambique, Brazil, Cape Verde, Goa and San Tome were understood as forming a fraternal community united by Portuguese language and culture; cultural and linguistic commonality was celebrated, while evidence of past colonial violence and inequality was discounted. This framework, in fact, continued Portuguese imperial mythologies of spiritual and cultural universalism, rebranding imperial ideologies of Portuguese colonial exceptionalism with late twentieth-century imaginaries of luso-tropicalism. ${ }^{48}$ This resignification of the colonial scientific past - and particularly the collections of the IICT - as a trace of lusophone solidarity represented, I believe, a mere mutation of the colonial chronotope of the anthropological missions, a mutation that allowed the mythology of empire ingrained in the data to persist in a post-colonial environment. The blood archive of indigenous 'primitives' from the Portuguese colonies now could, in theory, be revalued as a bond of 'cooperation' in a lusophone community, a monument to and nostalgic evidence of the 'common history' of Portuguese-speaking countries. In practice, however, the colonial and racialized remains of anthropobiology were left to sit marginally, if not uncomfortably, within the IICT heritage programme.

After the institutional end of the CEA in 2004, its collections were distributed through distinct centres and departments. In this context the destiny of the cards was under consideration. Whilst some defended the collections as a precious and inalienable legacy of the IICT, others eventually considered that the future of the cards would be best preserved by their transfer to a proper genetics laboratory in Portugal, where the samples could be adequately studied. ${ }^{49}$ The presidency decided that the cards were to remain in the possession of the IICT, and it was around this time that the cabinet was moved into the improvised storage room where I encountered it in 2013. Between 2004 and 2015, the cards cabinet remained there, waiting for an unknown destiny. Notwithstanding the rhetoric of 'lusophone heritage', then, by simply leaving it in a back room without any function, the IICT authorities apparently put the filing cabinet

47 Macedo eventually envisaged that the IICT would become a think tank of the CPLP. To this end he also managed to change its institutional place within the Portuguese state system: Macedo turned the IICT from a laboratory under the Ministry of Science into an institution under the tutelage of the Portuguese Ministry of Foreign Affairs. I thank Cláudia Castelo for this point.

48 Compare Cláudia Castelo, 'O Modo Português de Estar no Mundo': O Luso-tropicalismo e a Ideologia Colonial Portuguesa, Oporto: Afrontamento, 1998; Adriano de Freixo, 'Ecos do Luso-tropicalismo: a presença do pensamento de Gilberto Freyre no discurso da Lusofonia', Textos \& Debates (2015) 27(2), pp. 471-484.

49 It seems that among anthropobiologists the suitability of the IICT to continue to serve as the guardian of the collections was not consensual. In a conversation in 2013, Dr Maria Cristina Neto (Rosado Marques's former colleague at CEA) suggested that this was the case and referred to a struggle with Braga de Macedo's presidency over the fate of the blood samples. Neto eventually advocated the transfer of the samples to a genetics laboratory in northern Portugal, where in her view they could be more suitably preserved and put to scientific use. 
on hold, as if it was an unclassifiable leftover, a wreckage of the past left to decay and die. Only for a moment in 2010 did the cards emerge from their institutional shadow to play a small part in the official heritage discourse. It seems that, along with a number of anthropometric instruments and records from Almeida's anthropological missions, one example of a blood group card was put on display as part of a temporary exhibition set up by the IICT authorities to celebrate the former grandeur of the various 'scientific missions' to the Portuguese colonies. ${ }^{50}$

Against these odds, Rosado Marques maintained his belief that the blood archive was more than a vestige of the past until at least the late 2000s. He sought to avoid its appropriation by outsiders, whilst also preventing internal sceptics from disposing of the cards as useless waste. This labour was motivated by his belief that the samples could have value for a science with a clear present and future: genetics. He made efforts to reactivate the cards and translate the early promises of raciological knowledge into contemporary methods of population genetics, converting the collections' colonial chronotope into the present and future of genetic sciences. He first painstakingly recounted, reorganized and rearranged the card files in the wooden drawers, with a view to possible reuses of the blood samples as well as of the anthropometric data produced by Almeida's anthropobiological expeditions. Marques's reorganization agreed with the original distribution of the cards. Almeida and his daughter had arranged the cards into drawers labelled and classified according to the names of the former colonial territories and the names of the so-called 'ethnic groups'. In each drawer Marques counted and aggregated the cards according to the same ethnic labels, and added gender symbols. Lacking both the training (he was not a human geneticist) and technological facilities, he depended on others to fulfil his vision. Furthermore, Marques was not alone in his imagining hidden powers in the old blood samples. In the same period several Portuguese geneticists outside the IICT approached him, interested in reusing the blood samples. Marques negotiated controlled access to the cards. In collaboration with geneticists from universities in Oporto and Madeira, Marques sent a few cards on temporary loan to laboratories in Germany and in Slovenia for DNA analysis. There, attempts were made to extract DNA by scratching the dry blood off the paper cards. The procedure was abandoned; it was considered too expensive and unreliable. No further experiments were conducted.

By 2013, the very historical materiality of the blood group samples now impeded trustworthy laboratory analysis; it affected their durability as a biological source of genetic information from the Asian and African individuals from whom the blood had originally been extracted in the 1950s and 1960s. In the language of DNA genetic studies, the problem was one of 'contamination'; that is, the fact that the old cards contained DNA segments of 'foreign origin'. ${ }^{51}$ Marques understood the contamination problem as the product of 1950 s collecting procedures and ABO group determination.

50 Rosado Marques's personal information, June 2017. Yet photos of blood group cards do not appear in the published catalogue of the exhibition. Ana Cristina Martins and Teresa Albino (eds.), Viagens e Missões Científicas nos Trópicos 1883-2010, Lisbon: IICT, 2010.

51 See 'Contamination in sequence databases', at www.ncbi.nlm.nih.gov/tools/vecscreen/contam, accessed 2 October 2017. 
The cards did not contain human blood drops alone: in order to become blood group data the cards' dry drops were a mixture of blood and 1950s anti-sera, then an organic composition from many individuals. Thus the drops themselves were an inextricable confusion of DNA from many different individuals that could not be easily distinguished. Human geneticists, however, saw additional problems beyond the contamination inherent to anti-sera. From this viewpoint, inadequate preservation procedures adopted by the old CEA and its researchers had caused the samples to degrade. Dr Luis Souto de Miranda of the University of Aveiro was among the first geneticists to seek to use the colonial samples for a new project on forensics and population genetics in East Timor. According to Miranda, there were 'many [geneticists] interested' in the samples in the early 2000s. He told me he indeed considered reusing the cards, but after a visit to the CEA in 2000-2001 - a visit Miranda remembers felt like 'travelling back in time'- he was quick to discard this possibility because the 'collections', in his own words, 'are degraded' due to 'contamination' of the samples by decades of inadequate storage and manipulation. ${ }^{52}$ 'The problem of the collections made in the colonial period', he concluded, 'is that they do not endure'. Back in the 1950s, the paper cards for blood group classification were preferred by colonial anthropologists for their ease in mass collecting, their transportability, and the advantages of storage and use as paper files in the office. But, from the perspective of geneticists today, these methods of storage and manipulation inconveniently deteriorated the samples, leaving them too heavily 'contaminated' for reliable genetic analysis. From this viewpoint, the colonial cards failed to deliver the promise of durability; unworkable for DNA studies on the original indigenous populations they were deemed to represent, they are understood as if they are futureless, a dead vestige of the scientific past.

Marques may have lost some of his early faith in the future of the cards after this sequence of failed laboratory attempts. He lived with the cards differently thereafter, as if acknowledging they could serve principally as relic and reminder of past achievements in the Portuguese sciences. He stepped back from encouraging reuse by geneticists. In 2013, when he showed me the storage room, he had already retreated into the role of keeper of the material life of the card collections, as pieces of 'history'. Soon afterwards he broke his attachment to the card samples for good. In 2015, an unexpected institutional change brought the dreams of reform of the IICT to an end. Following a tense and politically convoluted institutional existence under Macedo's presidency, the Portuguese government decreed the 'extinction by fusion' of the IICT and the subsequent 'integration' of the IICT's staff, heritage and collections into Portugal's largest university, the University of Lisbon. ${ }^{53}$ During this process the cards were removed from the storage room and transferred into the National Museum of Natural History and Science at the University of Lisbon (MUHNAC), where they remain today. In this transfer, the cards were carefully packed and reinstalled inside the wooden drawers of the original

52 Interviews with Luís Souto de Miranda, Aveiro, October 2015 and January 2016.

53 Decreto-lei 141/2015, 31 July 2015; see also Despacho no 5970/2016, Reitoria da Universidade de Lisboa, through which the University of Lisbon delegates to the MUHNAC director the management of the IICT heritage. I thank Marta C. Lourenço for this reference. 
custom filing cabinet that contained them. They were also attributed a biologized identity by being considered natural-history collections: at MUHNAC the cards are currently stored, away from the general public, in the 'reserved' section of Zoology. ${ }^{54}$ In recent decades the treatment of the ancestral remains of indigenous peoples as biospecimens (including blood) has become highly ethically and politically sensitive, especially in the context of repatriation debates in Australia, New Zealand, Canada, the UK and the US. ${ }^{55}$ In this light the reanimation of the blood group cards as simple zoological specimens at MUHNAC in Lisbon is potentially problematic - to my knowledge, however, this theme has not yet been openly discussed. Indigenous African and Asian historicities and concepts remain absent in the career of the cards' colonial chronotopes.

Classifying the cards as 'contaminated' made the samples ineffective for contemporary geneticists interested in pursuing DNA studies of the indigenous 'populations' of the former Portuguese colonial empire. In judging the samples as failing to contain purely 'indigenous' biomaterials, however, new genetic science continued the colonial dream of the samples' scientific wealth. Although the samples could be put aside into a quasi-waste condition, it was still their value as evidence of ancient pure and authentic indigenous individuals that was at stake. The contamination label reiterated, through a process of negation, the colonial chronotope of the cards as a pathway to primitive biological pasts of 'indigenous' peoples. The colonial chronotope was not wrong per se, just inadequately executed. And yet, paradoxically, the geneticists' classification of the colonial samples as 'contaminated' makes room for a rather distinct critical analysis of the current post-coloniality of the blood archive. For one important reason why the blood cards are seen as 'contaminated' is because, over decades, they were in constant and intimate contact with their primary human users: the colonial collectors, and - above all - the scientists, the anthropobiologists, at Lisbon. Human DNA from António de Almeida, Maria Emília and Rosado Marques, for instance, may be materially inscribed into the card collections. The social, affective and material intimacy between humans and samples at the CEA - the association of anthropobiologists and blood cards - transformed the blood archive into a very distinct biobank. In so-called 'contaminated' cards, indigenous DNA is inextricable from that of colonial scientists. The paper cards have become carriers of data from the scientists' bodies themselves. They are no longer merely samples of indigenous populations, but biological relics of scientific occupation and of its aftermath. This apparently remarkable twist in the bio-material constitution of the paper cards was caused by their social and historical trajectory as a 'colonial and racialized collection'. In other words, the social life of cards in the hands of scientists turned the cards into bio-records of their own historicity; it transformed the biological nature of the paper archive, and ultimately it undermined the possibility of a scientific future in genetics. In this silent transformation of the cards' materiality, perhaps, we can see the racial politics of science and collecting being undone, the original colonial

54 Catarina Teixeira, email, 10 May 2018 (kindly forwarded by Marta C. Lourenço).

55 See, for example, Kowal, Radin and Reardon, op. cit. (2); Paul Turnbull and Michael Pickering (eds.), The Long Way Home: The Meaning and Values of Repatriation, Oxford: Berghahn Books, 2010; Emma Kowal, 'Orphan DNA: indigenous samples, ethical biovalue and postcolonial science', Social Studies of Science (2013) 43, pp. 577-597. 
chronotope potentially subverted. None of these considerations, however, has yet entered discussions or current understandings of the collections in their current lives as museum objects.

In entering the museum in 2015, the cards became collections of zoology, emanations of the natural world that contained scientific knowledge in potentia - not simply in relation to the biological nature of the archived blood, but also in relation to the cards as evidence of a bygone epoch of science. In early 2017, I met with the curator of anthropological collections and the museum technicians responsible for the care and conservation of the materials. For the curator as well as for the conservator, the cards are to be treated according to rigorous technical procedures of conservation in order to endure a physical life in the museum storeroom. As material conservation proceeds, the written information stored in the cards is separated from the cards, extracted and transformed into a digital database. Now that geneticists have declared that the blood itself is unsuitable for genetic analysis, blood cards and written data are set apart from each other. Thus the words inscribed on the cards (donor, blood group, etc.) are the object of a classificatory and informational curatorship. And yet, I believe, the capacity of the blood archive to articulate historicities of race, science and empire in the present is not simply dead; it lies dormant. Unlike geneticist Luís de Miranda, who understands the collections as useless remains of the scientific past, museum curators treat the cards as latent scientific 'sources' - sleeping data without present effect, but with an imagined future in the sciences that has been only temporarily deactivated. 'I cannot see these collections as "ruined” or “abandoned”,' MUHNAC deputy director Marta C. Lourenço observed in her response to an earlier version of this essay: 'I see them as sources, as scientific collections. They may be “dormant", like an archive, but they can answer so many research questions about the past, the present and even the future.' This may point to yet unknown uses in the biological sciences, but also to the cards' capacity to be animated by stories about a time that lies behind. 'They are alive', Lourenço added, 'to tell many stories about the past of the sciences and the past of Portugal to present and future researchers and general audiences'. ${ }^{56}$ This perceived potency of the card collections as dormant elicitors of future knowledge about 'the past of the sciences and the past of Portugal' restricts their condition to containers of a past time of national history that is no more. This may explain why they are kept safely and durably in a museum vault. Prior to their return to the wooden drawers I saw the sets of cards being wrapped up in cloth and cardboard boxes at the Natural History and Science Museum in Lisbon. The careful conservation procedure resembled a funerary rite on dangerous corpses, as if the cards contained the essence of a departed colonial science - and some yet unknown potency to be duly safeguarded and controlled but also kept out of sight.

56 Marta C. Lourenço, personal communication by email, 13 May 2018. 


\section{Conclusion: staying with the contamination}

Throughout its journey from the ex-colonies to Lisbon in the 1950s, to the museum in the 2010s, and via various scientific institutions in between, the cards archive became increasingly infused with temporal imaginaries; at the same time, its own sociomaterial life paved the way to unintended temporalities. I have imagined the blood cards as a mutating and multiple colonial chronotope. The concept of colonial chronotope was here advanced to shed light on the history of scientific collections as plastic configurations of colonial time-spaces. The idiom of 'mutations', as proposed by Kowal, Radin and Reardon, thus can be enriched by conceptualizing collections as chronotopes that both can be acted upon and be an actor of their own shifting colonial and racial temporalities. To assign these time-space twists to the idiom of imperial 'ruins' alone, however, deters us from addressing the multiple temporal ontologies that may activate, or be activated by, the existence of 'what remains' from empires - such as colonial collections. For, as demonstrated above, ruin, waste or debris - as seen when geneticists declared the cards to be useless contaminated entities - were one possible quality among many that biomaterials could adopt throughout their social lives. This by no means represented their end as scientific collections; as specimens of imagined latent epistemic potency they remain stored in the museum. There, the blood cards, however, continue to bear witness to collections as colonial chronotopes.

The cards shifted from embodying visions of scientific value in the present and in the future to a latent condition as a residue of the past, and from embodying visions of imperial futures to encapsulating the promises of a benign lusofonia. Simultaneously, the accumulation of temporal imaginaries in the cards was followed by the accumulation of DNA fragments, temporal records themselves. Hence the ends of the blood group cards as collections are to be conceptualized, I believe, not as ends de facto but as mutations of their constitutive colonial chronotopes. As racialized markers, the cards condensed the dreams of post-war Portuguese colonial racial science. At the CEA, the collection consolidated an original scientific community of self-fashioned 'anthropobiologists'. There, as a treasured possession of Almeida and his daughter, they were an object of personal care and affect, a source of scientific authority, and a mediator of notions of human difference and affinity across the Portuguese overseas world. But, as time went by, the visions embodied in the archive lost touch with the world outside the centre. The collective entities, such as 'empire' and 'anthropobiology', that the blood cards articulated and were meant to hold together in their microscopic materiality lost their concrete existence. The empire was dismantled; colonial raciology and sero-anthropology lost credibility; their collectors, carers and users aged and died. In the 2000s the society of anthropobiologists and their blood cards effectively came to an institutional end. The few anthropobiologists who survived the end of the colonial empire and the transformations of the CEA, however, lived with this material as things that were fully coeval with their existences and careers. The colonial chronotope of the collection proved to be resilient; rather than disappearing, it underwent several mutations. Over the years, the collections' promises were not fulfilled. Yet, for some, even with the demise of the Portuguese empire, the blood cards maintained an embellished colonial 
past in the form of lusophone heritage; for others, they still contained genetic value as long as 'biodata' on colonized indigenous people could be extracted. Thus anthropobiologists and, later on, human geneticists saw the cards as continuing carriers of epistemic value congruent with the data-extraction imageries of colonial sciences. Beyond their (failed) links to present science, the collections were enrolled in post-colonial imaginaries of heritage that translated hopes of future prosperity and community in the idiom of lusofonia. Once declared genetically contaminated, however, they were deprived of an imagined future in genetics. Geneticists then abandoned hopes of extracting from the old collections further biodata on indigenous populations, looking at the cards as obsolete, a kind of scientific waste of the past. They then entered a museum vault as dormant specimens of yet unknown scientific value, in which their part in the present seems also to be that of a national quasi-relic of past Portuguese sciences. Throughout this history of transformations, however, no indigenous presents or futures were yet invoked or invited to play an active role. This lasting absent intervention of donors and their descendants may contrast with situations - repatriation processes being the most paradigmatic - in which the colonial chronotopes of collections are reconfigured, or actually terminated, with the active involvement of indigenous people.

And yet, I also argue that if we consider the collections' genetic contamination to be a generative, rather than negative, property, this may pave the way to a critique of the samples' colonial chronotope. Whilst geneticists see impurity as a problem, I see it as the possibility of new post-colonial imaginings. Throughout their social life, the cards themselves came to coalesce different times and the biologies of different subjects. This effervescent biosocial agency of the cards over the course of their existences acts to interfere with the original colonial divides and extractive imaginaries that, nonetheless, simultaneously persist strongly in these collections. This may not simply undo these divides and imaginaries - but it adds to the cards' existence an unexpectedly subversive conjunction that is worth taking into account. The DNA patterns of scientists and indigenous people, of different eras and locales, dwell together on the cards. DNA fragments of Almeida in the 1950s, of Castro e Almeida in the 1960s, of Rosado Marques in the 2000s, of other unknown users, and finally of a multitude of indigenous subjects (most of whom would now be dead) from Timor and Angola in the 1940s and 1950s have come to co-constitute the materiality of the samples. This tense ontological coexistence of distinct times and human traces is perhaps one final, though silent, mutation in the multiple colonial chronotope of the cards. The cards resiliently evoke in their existence the colonial imbalances and racialized constructs by which they were created. But over their existence they also became co-producers of an unintended cohabitation of times and of people that were deemed to exist separately. Hence inspired by feminist and science studies scholar Donna J. Haraway, I conclude by imagining the blood group cards today as microscopic 'relational-semiotic worldings' in which 'ontologically heterogeneous partners' live with, and 'become-with', one another. ${ }^{57}$ In 'staying with' the trouble of their present contamination, we are invited

57 Donna J. Haraway, Staying with the Trouble: Making Kin in the Chthulucene, Durham, NC: Duke University Press, 2016, pp. 12-13. 
to consider these collections as mediators of neither ends nor beginnings. Instead, we are called to look upon them as troubling biosocial entities where spatiotemporally diverse bodily traces and gestures are inscribed and coexist in ongoing tension. 